\title{
Identification, localization and expression of LPXRFamide peptides, and melatonin-dependent induction of their precursor mRNA in the newt brain
}

\author{
Vishwajit Sur Chowdhury*, Takayoshi Ubuka, Tomohiro Osugi, Taichi Shimura and Kazuyoshi Tsutsui \\ Laboratory of Integrative Brain Sciences, Department of Biology, Center for Medical Life Science of Waseda University, Waseda University, 2-2 Wakamatsu-cho, \\ Shinjuku-ku, Tokyo 162-8480, Japan \\ (Correspondence should be addressed to K Tsutsui; Email: k-tsutsui@waseda.jp) \\ *(V S Chowdhury is now at Department of Bioresource Sciences, Faculty of Agriculture, Kyushu University, Fukuoka 812-8581, Japan
}

\begin{abstract}
The existence of RFamide peptides with a C-terminal LPXRFamide $(\mathrm{X}=\mathrm{L}$ or $\mathrm{Q})$ motif has been identified in the brain of various vertebrate species. However, the presence of LPXRFamide peptides in the urodele brain is not yet known. In this study, we cloned a cDNA encoding the precursor of LPXRFamide peptides from the newt brain by a combination of $3^{\prime}$ and $5^{\prime}$ rapid amplification of cDNA ends. The deduced LPXRFamide peptide precursor consisted of 233 amino acid residues, encoding four putative LPXRFamide peptides. All the peptide sequences were flanked by a glycine C-terminal amidation signal and basic amino acid on each end as an endoproteolytic site. Mass spectrometric analyses detected a nonapeptide, two decapeptides and an octapeptide produced from the precursor polypeptide in the brain as endogenous ligands. In situ hybridization further revealed the cellular localization of
\end{abstract}

newt LPXRFamide (nLPXRFa) precursor mRNA in the suprachiasmatic nucleus ( $\mathrm{SCN}$ ) in the newt hypothalamus. Immunocytochemistry showed a cluster of cell bodies restricted to the SCN and their terminals in the median eminence. To understand the regulatory mechanism of nLPXRFa peptide expression, we further analyzed the effect of melatonin on the expression of nLPXRFa precursor mRNA. Melatonin administration to newts increased the expression of nLPXRFa precursor mRNA in the diencephalon. These results indicate that the urodele hypothalamus possesses LPXRFamide peptides and the expression of LPXRFamide peptides is regulated by melatonin. The localization of nLPXRFa peptides further suggests that these peptides may be involved in the regulation of pituitary hormone release in newts.

Journal of Endocrinology (2011) 209, 211-220

\section{Introduction}

The molluscan neuropeptide Phe-Met-Arg-Phe- $\mathrm{NH}_{2}$ (FMRFa) was discovered in the ganglia of the venus clam (Price \& Greenberg 1977), and it was suggested that the vertebrate hypothalamus possesses some unknown neuropeptides similar to FMRFa (Raffa 1988, Rastogi et al. 2001). In fact, over the past decade, neuropeptides that have the ArgPhe- $\mathrm{NH}_{2}(\mathrm{RFa})$ motif at their C-termini have been identified in the brains of several vertebrates. Based on the structures of vertebrate RFa peptides, to date, at least five groups of the RFa peptide family have been documented (for reviews, see Ukena \& Tsutsui 2005, Tsutsui \& Ukena 2006, Osugi et al. 2006). Among these groups of the RFa peptide family, the LPXRFamide (X $=\mathrm{L}$ or $\mathrm{Q}$ ) peptide (LPXRFa peptide) group is considered to be the largest one. We recently identified several LPXRFa peptides in the brain of various vertebrates. We first identified a novel neuropeptide with a C-terminal LPLRFa motif in the quail brain (Tsutsui et al. 2000). It was shown that this avian neuropeptide was located in the hypothalamohypophysial system (Tsutsui et al. 2000, Ubuka et al. 2003, Ukena et al. 2003a) and decreased gonadotropin release in vitro (Tsutsui et al. 2000) and in vivo (Osugi et al. 2004, Ubuka et al. 2006, Chowdhury et al. 2010). We therefore designated this neuropeptide as gonadotropin-inhibitory hormone $(\mathrm{GnIH}$; Tsutsui et al. 2000). Subsequently, several neuropeptides which were closely related to $\mathrm{GnIH}$ were identified in the brains of other vertebrates, such as mammals (RFamide-related peptides (RFRPs), Fukusumi et al. 2001, Ukena et al. 2002, Yoshida et al. 2003, Ubuka et al. 2009a,b), frogs (frog GH-releasing peptide (fGRP), Koda et al. 2002, Ukena et al. 2003b; Rana RFamide (R-RFa), Chartrel et al. 2002) and fish (goldfish (gf) LPXRFa, Sawada et al. 2002b, Amano et al. 2006). Thus, it is becoming clear that $\mathrm{GnIH}$ and its orthologs having a common C-terminal LPXRFa motif (LPXRFa peptides) are synthesized in the brain in a variety of vertebrates (for reviews, see Ukena \& Tsutsui 2005, Tsutsui \& Ukena 2006, Tsutsui 2009, 2010, Tsutsui \& Osugi 2009, Tsutsui et al. 2010a,b). 
Seasonal breeding amphibians serve as excellent animal models to understand physiological roles of $\mathrm{GnIH}$ and its orthologs (LPXRFa peptides) and their regulatory mechanisms. Recently, a novel neuropeptide with a C-terminal LPLRFa sequence was identified in the bullfrog (fGRP; Koda et al. 2002) and European green frog brain (R-RFa; Chartrel et al. 2002). Molecular cloning of cDNA encoding the precursor of fGRP further exhibited that it encodes fGRP and its related peptides (fGRP-RPs; Sawada et al. 2002a). fGRP and fGRP-RPs were invariably equipped with -LPXRF (X=L or Q) at their C-termini (Koda et al. 2002, Sawada et al. 2002a, Ukena et al. 2003b). In amphibians, GnIH orthologs (fGRP and its related peptides) having a common C-terminal LPXRFa motif have been identified only in frogs, anuran species. However, the presence of GnIH orthologs in the urodele brain is unclear. To generalize the presence of $\mathrm{GnIH}$ orthologs in amphibians, it is imperative to identify $\mathrm{GnIH}$ orthologs in newts, the urodele species. Therefore, the first aim of this study was to identify GnIH orthologs (LPXRFa peptide) in the newt brain. In the present study, we sought to identify a cDNA encoding the LPXRFa peptide precursor polypeptide and its mature endogenous peptides in the newt brain. The localization of its transcript in the newt brain was further investigated. To understand the physiological role of LPXRFa peptides, it is essential to know the factor that regulates the expression of LPXRFa peptides. Therefore, the second aim was to determine the regulation of the expression of the identified newt $\mathrm{GnIH}$ orthologs (LPXRFa peptide) by melatonin because this nocturnal hormone acts to regulate the expression of $\mathrm{GnIH}$ and its orthologs in birds and mammals (Ubuka et al. 2005, Mason et al. 2010). We therefore analyzed the effect of melatonin administration on the expression of LPXRFa peptide precursor mRNA in the newt brain.

\section{Materials and Methods}

\section{Animals}

Adult male Japanese red-bellied newts (Cynops pyrrhogaster) were collected and used in the present study. Newts were kept in ordinary water aquariums maintained at $18 \pm 2{ }^{\circ} \mathrm{C}$ under a daily photoperiod cycle of $12 \mathrm{~h}$ light: $12 \mathrm{~h}$ darkness (lights on at $0700 \mathrm{~h}$ ). The experimental protocols were approved in accordance with the Guide for the Care and Use of Laboratory Animals of Waseda University (Tokyo, Japan).

\section{$R N A$ preparation and amplification of the partial $n L P X R F a$ peptide cDNA fragments}

Total RNA of the brain was extracted with Sepasol-RNA I Super (Nacalai Tesque, Kyoto, Japan), in accordance with the manufacturer's instructions. All PCR amplifications were carried out in a reaction mixture containing Taq polymerase (Ex Taq polymerase (Takara Shuzo, Kyoto, Japan) or gene
Taq polymerase (Nippon Gene, Tokyo, Japan)) on a thermal cycler (Program Temp Control System PC-700, ASTEC, Fukuoka, Japan). First-strand cDNA was synthesized with the oligo(dT)-anchor primer supplied in the $5^{\prime} / 3^{\prime}$ rapid amplification of cDNA ends (RACE) kit (Roche Diagnostics) and amplified with the anchor primer (Roche Diagnostics) and the first degenerate primers $5^{\prime}-(\mathrm{T} / \mathrm{C}) \mathrm{TIA}-$ A(A/G)CCIGCIGCIAA(T/C)(T/C)TICC-3' ${ }^{\prime}$ (I represents inosine), corresponding to the fGRP sequence $\mathrm{Leu}^{2}-\mathrm{Lys}^{3}-$ $\mathrm{Pro}^{4}-\mathrm{Ala}^{5}-\mathrm{Ala}^{6}-\mathrm{Asn}^{7}-\mathrm{Leu}^{8}-\mathrm{Pro}{ }^{9}$ (Koda et al. 2002). First-round PCR products were re-amplified with the first degenerate primer and the second degenerate primers $5^{\prime}$-GCIAA(T/C)(T/C)TICCI(T/C)TI(C/A)GITT(T/C)GG-3' , corresponding to the fGRP sequence $\mathrm{Ala}^{6}-\mathrm{Asn}^{7}-\mathrm{Leu}^{8}-\mathrm{Pro}^{9}-\mathrm{Leu}^{10}-\mathrm{Arg}^{11}{ }^{1}$ $\mathrm{Phe}^{12}-\mathrm{Gly}^{13}$ (Koda et al. 2002). Both first-round and secondround PCRs consisted of 30 cycles of $30 \mathrm{~s}$ at $94^{\circ} \mathrm{C}, 30 \mathrm{~s}$ at $51{ }^{\circ} \mathrm{C}$ and $1 \mathrm{~min}$ at $72{ }^{\circ} \mathrm{C}$. The second-round PCR products were subcloned into a pGEM-T Easy vector in accordance with manufacturer's instructions (Promega). The DNA inserts of the positive clones were amplified by PCR with universal M13 primers.

\section{Determination of the $3^{\prime}$-end sequence of $n L P X R F a$ peptide cDNA}

First-strand cDNA was synthesized as described above and amplified with the anchor primer and gene-specific primer 1 (5'-CTGGAAGAAGCAAAAAGTAG-3', corresponding to nt 340-360). The PCR was performed for 30 cycles consisting of $1 \mathrm{~min}$ at $94{ }^{\circ} \mathrm{C}, 1 \mathrm{~min}$ at $55^{\circ} \mathrm{C}$ and $1 \mathrm{~min}$ at $72^{\circ} \mathrm{C}$. The PCR products were subcloned and the inserts were amplified as described above.

\section{Determination of the $5^{\prime}$-end sequence of nLPXRFa peptide cDNA}

Template cDNA was synthesized with an oligonucleotide primer complementary to nt 461-480 (5'-GGCTGGATGGAACGTTTGCT-3'); this synthesis was followed by dA-tailing of the cDNA with dATP and terminal transferase (Roche Diagnostics). The tailed cDNA was amplified with the oligo(dT)-anchor primer and gene-specific primer 2 (5'-CGTCCAAATCTCTGTGGTAA-3', complementary to nt 431-450); this was followed by further amplification of the first-round PCR products with the anchor primer and gene-specific primer 3 (5'-TTCGGGACACTTTTACGAAT- $3^{\prime}$, complementary to nt 410-428). Both first-round and second-round PCRs were performed for 35 cycles consisting of $1 \mathrm{~min}$ at $94^{\circ} \mathrm{C}, 1 \mathrm{~min}$ at $55^{\circ} \mathrm{C}$ and $1 \mathrm{~min}$ at $72{ }^{\circ} \mathrm{C}$. The second-round PCR products were subcloned and the inserts were amplified as described above.

\section{DNA sequencing}

All nucleotide sequences were determined with a Thermo Sequence cycle sequencing kit (Amersham Pharmacia 
Biotech), IRDye 800 termination mixes version 2 (NEN Life Science Products, Boston, MA, USA), and a model 4200-1 G DNA sequencing system and analysis system (LI-COR, Lincoln, NE, USA), then analyzed with DNASIS-MAC software (Hitachi Software Engineering). Universal M13 primers or gene-specific primers were used to sequence both strands.

\section{Immunoaffinity purification and mass spectrometry}

To identify endogenous mature peptides in the newt brain, we carried out affinity purification and immunoassay with the antiserum raised against fGRP. Brains $(n=200)$ were boiled for $7 \mathrm{~min}$ and homogenized in 5\% acetic acid, as described previously (Tsutsui et al. 2000, Koda et al. 2002, Ukena et al. $2003 \mathrm{~b}$ ). The homogenate was centrifuged at $15000 \mathrm{~g}$ for $20 \mathrm{~min}$ at $4{ }^{\circ} \mathrm{C}$ and the supernatant was collected. After precipitation with $75 \%$ acetone, the supernatant was passed through a disposable C-18 cartridge column (Mega BondElut; Varian, Harbor, CA, USA) and the retained material (RM) eluted with 60\% methanol was loaded onto an immunoaffinity column. The affinity chromatography was carried out as described elsewhere (Sawada et al. 2002b, Ukena et al. 2002, 2003b, Osugi et al. 2006, Ubuka et al. 2008, $2009 a, b)$. The antibodies against fGRP were conjugated to $\mathrm{CNBr}$-activated Sepharose $4 \mathrm{~B}$ as an affinity ligand. The brain extract was applied to the immunoaffinity column at $4{ }^{\circ} \mathrm{C}$ and the adsorbed materials were eluted with $0.3 \mathrm{M}$ acetic acid containing $0 \cdot 1 \% 2$-mercaptoethanol. The eluted fractions were concentrated and subjected to a reversed-phase HPLC column (ODS-80TM; Tosoh, Tokyo, Japan) with two-step gradients of acetonitrile (20-27\%/35 $\mathrm{min} ; 27-47 \% / 65 \mathrm{~min})$ containing $0 \cdot 1 \%$ trifluoroacetic acid at a flow rate of $0.5 \mathrm{ml} / \mathrm{min}$, and fractioned every $2 \mathrm{~min}$ for $100 \mathrm{~min}$. The immunoreactive fractions were assayed by a dot immunoblot assay, and the molecular mass of the materials were analyzed by matrix-assisted laser desorption/ionization time of flight mass spectrometry (MALDI-TOF MS) (AXIMA-CFR plus; Shimadzu, Kyoto, Japan). The predicted nLPXRFa-1 (SVPNLPQRFa), nLPXRFa-2 (MPHASANLPLRFa), nLPXRFa-3 (SIQPLANLPQRFa) and nLPXRFa-4 (APSAGQFIQTLANLPQRFa) were synthesized by peptide synthesizer (PSSM-8, Shimadzu), and molecular behavior of the synthetic and native peptides were further compared using MALDI-TOF MS.

\section{In situ hybridization of $n L P X R F$ a peptide $m R N A$}

The site of nLPXRFa peptide mRNA expression in the brain was localized by in situ hybridization. In brief, adult newts were killed by decapitation. After dissection from the skull, the brains were fixed in 4\% paraformaldehyde in PBS $(\mathrm{pH}$ $7 \cdot 3$ ) overnight at $4{ }^{\circ} \mathrm{C}$ and then soaked in a refrigerated sucrose solution (30\% sucrose in PBS) until they sank. Whole brains were embedded in OCT compound (Miles, Inc., Elkhart, IN, USA) and freeze-sectioned frontally at $10 \mu \mathrm{m}$ thickness with a cryostat at $-20{ }^{\circ} \mathrm{C}$. The sections were placed onto 3-aminopropyltriethoxysilane-coated slides. In situ hybridization was carried out on the whole brain sections according to our previous method (Ukena et al. 1999, Osugi et al. 2004), using the DIG-labeled antisense RNA probe. Control for specificity of the in situ hybridization of nLPXRFa peptide mRNA was performed using the DIGlabeled sense RNA probe, which was complementary to the antisense probe.

\section{Immunohistochemistry}

Immunohistochemical analysis was conducted using the antiserum raised against fGRP in a rabbit, as described previously (Koda et al. 2002). This anti-fGRP serum was confirmed to recognize specifically three nLPXRFa peptides (nLPXRFa-1, -2 and -3 ), by a competitive ELISA. The $\mathrm{IC}_{50}$ values (concentrations yielding $50 \%$ displacement) in the competitive ELISA were estimated as follows: $9 \cdot 0 \mathrm{nM}$ for nLPXRFa-1 (SVPNLPQRFa), 18.9 nM for nLPXRFa-2 (MPHASANLPLRFa), $16.9 \mathrm{nM}$ for nLPXRFa-3 (SIQPLANLPQRFa), $14 \cdot 4 \mathrm{nM}$ for fGRP (SLKPAANLPLRFa) and more than $10000 \mathrm{nM}$ for other RFamide peptides, e.g. human PrRP (TPDINPAWYASRGIRPVGRFa), human NPFF (FLFQPQRFa) and human Kiss10 (YNWNSFGLRFa). Immunohistochemical analysis was performed as described previously (Tsutsui et al. 2000, Koda et al. 2002, Ukena et al. 2003a, Chowdhury et al. 2008). In brief, adult newts were killed by decapitation, and brains were fixed as described above. The whole brain was frontally or sagittally frozen-sectioned at $10 \mu \mathrm{m}$ thickness on a cryostat at $-20{ }^{\circ} \mathrm{C}$. Endogenous peroxidase activity was eliminated from the sections by incubation with $0 \cdot 3 \% \mathrm{H}_{2} \mathrm{O}_{2}$ in absolute methanol for $10 \mathrm{~min}$. After blocking nonspecific binding components, the sections were immersed in the primary antiserum against fGRP at a dilution of 1:1000 (Koda et al. 2002). Immunoreactive products were detected with an ABC kit (Vectastain Elite Kit; Vector Laboratories, Inc., Burlingame, CA, USA), followed by diaminobenzidine reaction, according to our previous method (Tsutsui et al. 2000, Ukena et al. 2003a). The specificity of the staining was assessed by substituting the antiserum with antiserum (1:1000 dilution) that had been preadsorbed by incubating with the antigen (synthetic nLPXRFa-1, -2 and -3) in a saturating concentration $(50 \mu \mathrm{g} / \mathrm{ml})$ overnight before use. The localization of immunoreactive cell bodies and fibers in the brain was studied using an Olympus $\mathrm{BH}-2$ microscope.

\section{Analysis of the effect of melatonin on $n L P X R F a$ precursor $m R N A$ expression}

Newts were administered with melatonin through i.p. injection or loading in ordinary water aquariums. For i.p. injection, melatonin $(10 \mu \mathrm{g}$ melatonin in $50 \mu \mathrm{l}$ saline) or vehicle $(50 \mu \mathrm{l}$ saline) was injected, and brain samples were collected after $1 \mathrm{~h}$ of injection. For loading in aquariums, 
Table 1 PCR primers used to produce standard-DNA and competitor-DNA for competitive PCR in the newt brain

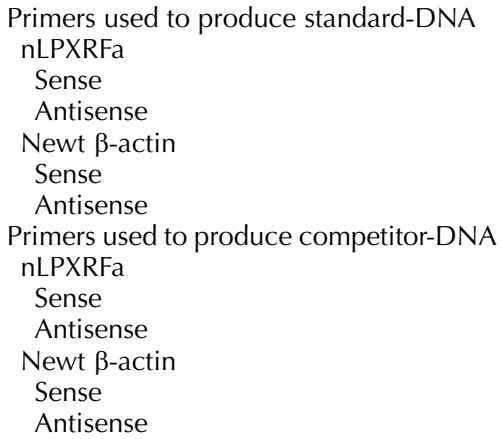

\author{
5'-CGCTTCGGCTAATTTACCAC-3' \\ 5'-ATAGCCAGATTCTTGGCCAC-3' \\ 5'-CACGGTATTGTCACCAACTG-3' \\ 5'-AGGCAGGGCATAACCTTCAT-3' \\ 5'-CGCTTCGGCTAATTTACCACCCTCTGAGATACGAAAGCGC-3'
5'-ATAGCCAGATTCTTGGCCAC-3' \\ 5'-CACGGTATTGTCACCAACTGCCCCAGAGGAACATCCTGTA-3' \\ 5'-AGGCAGGGCATAACCTTCAT-3'
}

melatonin ( $2 \mathrm{mg}$ melatonin in 21 water) or vehicle (2 1 water) was added into water aquariums twice in a week and newts were allowed to move freely in the aquarium. Brain samples from newts were collected after 1 week of loading with melatonin or vehicle. In both experiments, newts were kept under continuous light. To quantify the newt LPXRFa peptide precursor mRNA, competitive PCR analysis was performed as described previously (Chowdhury et al. 2010), with a little modification. The newt brains were removed and snap-frozen immediately in liquid nitrogen. Total RNA (including rRNA and mRNA) was isolated by the Sepasol extraction method (Sepasol-RNA I Super; Nacalai Tesque) from newt brains and reverse transcribed using oligo (deoxythymidine) $12-18$ primer (Amersham Pharmacia Biotech) and reverse transcriptase (M-MLV Reverse Transcriptase; Promega). Standard and competitor DNAs for competitive PCR analysis of the precursor nLPXRFa peptide were produced by PCR, using CDNA generated from the newt brain and primers indicated in Table 1. The PCR was conducted at $94^{\circ} \mathrm{C}$ for $3 \mathrm{~min}$, then 30 cycles at $94{ }^{\circ} \mathrm{C}$ for $1 \mathrm{~min}, 60^{\circ} \mathrm{C}$ for $1 \mathrm{~min}$ and $72^{\circ} \mathrm{C}$ for $1 \mathrm{~min}$, with an additional incubation at $72{ }^{\circ} \mathrm{C}$ for $3 \mathrm{~min}$. PCR products were spectrometrically quantified and each aliquot was used as standard or competitor DNA.

For competitive PCR, an aliquot of the cDNA solution corresponding to $1 \mu \mathrm{g}$ initial total RNA of each sample or standard DNA (30-3000 zmol/tube) were used as templates. Competitor DNA (300 zmol/tube) was equally applied to sample and standard tubes. PCR primers used for competitive PCR were the same as the primers which were used to produce standard DNA. The sense and antisense primers amplified a native $340 \mathrm{bp}$ fragment of the nLPXRFa peptide precursor gene from sample or standard DNA, and co-amplified competitor DNA (284 bp) equally diluted in the reaction mixture. The PCR was conducted at $94{ }^{\circ} \mathrm{C}$ for $3 \mathrm{~min}$, then 30 cycles at $94{ }^{\circ} \mathrm{C}$ for $1 \mathrm{~min}, 54{ }^{\circ} \mathrm{C}$ for $1 \mathrm{~min}$ and $72{ }^{\circ} \mathrm{C}$ for $1 \mathrm{~min}$, with an additional incubation at $72^{\circ} \mathrm{C}$ for $10 \mathrm{~min}$. PCR products were quantified by fluorescence of ethidium bromide on a $3 \mathrm{UV}$ Transilluminator (UVP, Inc., Upland, CA, USA) and subsequent two-dimensional analysis of the gel image with an NIH Image software package (National Institutes of Health, Bethesda, MD, USA). Intensity data so derived were subjected to quantitative analysis to calculate the nLPXRFa peptide precursor mRNA concentration. Standard or competitor DNA for competitive PCR analysis of a housekeeping gene, $\beta$-actin, was also produced by PCR using primers listed in Table 1 . For $\beta$-actin competitive PCR, an aliquot of the cDNA solution corresponding to $1 \mu \mathrm{g}$ initial total RNA of each sample or standard (10-1000 amol/tube) were used as templates. Competitor DNA (100 amol/tube) was equally applied to sample and standard tubes. PCR primers used for competitive PCR were the same as the primers which were used to produce standard DNA. The sense and antisense primers amplified a native $300 \mathrm{bp}$ fragment of the $\beta$-actin gene from

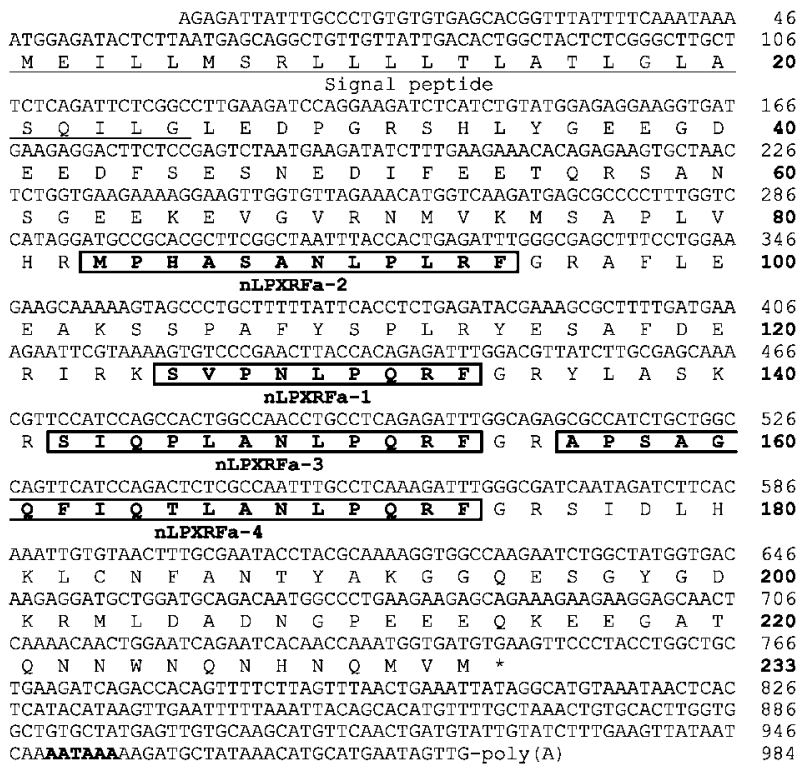

Figure 1 Nucleotide sequence and deduced amino acid sequence of $n L P X R F a(X=L$ or $Q)$ peptide precursor polypeptide cDNA. The identified nLPXRFa peptide sequences are boxed. The signal peptide is underlined. The asterisk indicates the stop codon. The poly(A) adenylation signal AATAAA is shown in bold. 
standard or sample DNA, and co-amplified competitor DNA (247 bp) equally diluted in the reaction mixture. PCR products were quantified and the $\beta$-actin mRNA concentration was calculated. nLPXRFa peptide precursor mRNA level was normalized with $\beta$-actin mRNA concentration and expressed as a ratio of nLPXRFa peptide precursor mRNA concentration to $\beta$-actin mRNA concentration in the corresponding total RNA derived from each brain sample.

\section{Statistical analysis}

Results of the competitive PCR were expressed as the mean \pm s.E.M. and analyzed for significance by Student's $t$-test.

\section{Results}

Characterization of a $c D N A$ encoding the $n L P X R F a$ peptide precursor polypeptide

To obtain LPXRFa peptide precursor cDNA fragments from the newt brain, we first performed an RT-PCR experiment with degenerate primers corresponding to the partial fGRP sequence and the anchor primer, which was followed by the re-amplification of the first-round PCR products with degenerate primers corresponding to the other partial fGRP sequence and the same anchor primer. Here, the C-terminal amide group was thought to be derived from a C-terminal Gly residue, which is known to be a typical amidation signal (Bradbury et al. 1982, Suzuki et al. 1990, Eipper et al. 1991). Electrophoresis of the nested PCR mixture revealed a major product of $\approx 0.6 \mathrm{~kb}$ (not shown). The predicted amino acid sequence included three copies of the potential RFamide peptide sequence, LPQRFG, downstream of the partial fGRP sequence derived from the second-round PCR primer, implying that this cDNA clone encoded also an RFamide peptide, including a C-terminal sequence similar to that of fGRP (LPLRFa). To determine the $5^{\prime}$-end sequence, we performed $5^{\prime}$ RACE with specific primers for the clone. A single product of $\approx 0.5 \mathrm{~kb}$ (results not shown) was obtained and sequenced, revealing that these cDNA clones contained a LPLRFG sequence. The entire nLPXRFa peptide precursor cDNA was identified by combining nucleotide sequences determined by RACE experiments. As shown in Fig. 1, the deduced nLPXRFa peptide precursor encoded one LPLRFa peptide and three LPQRFa peptides. The nLPXRFa peptide precursor cDNA was composed of 984 nt containing a short $5^{\prime}$ untranslated sequence of $46 \mathrm{bp}$, a single open reading frame of $699 \mathrm{bp}$ and a $3^{\prime}$ untranslated sequence of $239 \mathrm{bp}$ with the addition of various length of poly(A) tail. The open reading frame region began with a start codon at position 47 and terminated with a TGA stop codon at position 748 . The nucleotide sequence data reported will appear in DDBJ, EMBL and GenBank Nucleotide Sequence Databases under the accession number AB537567.
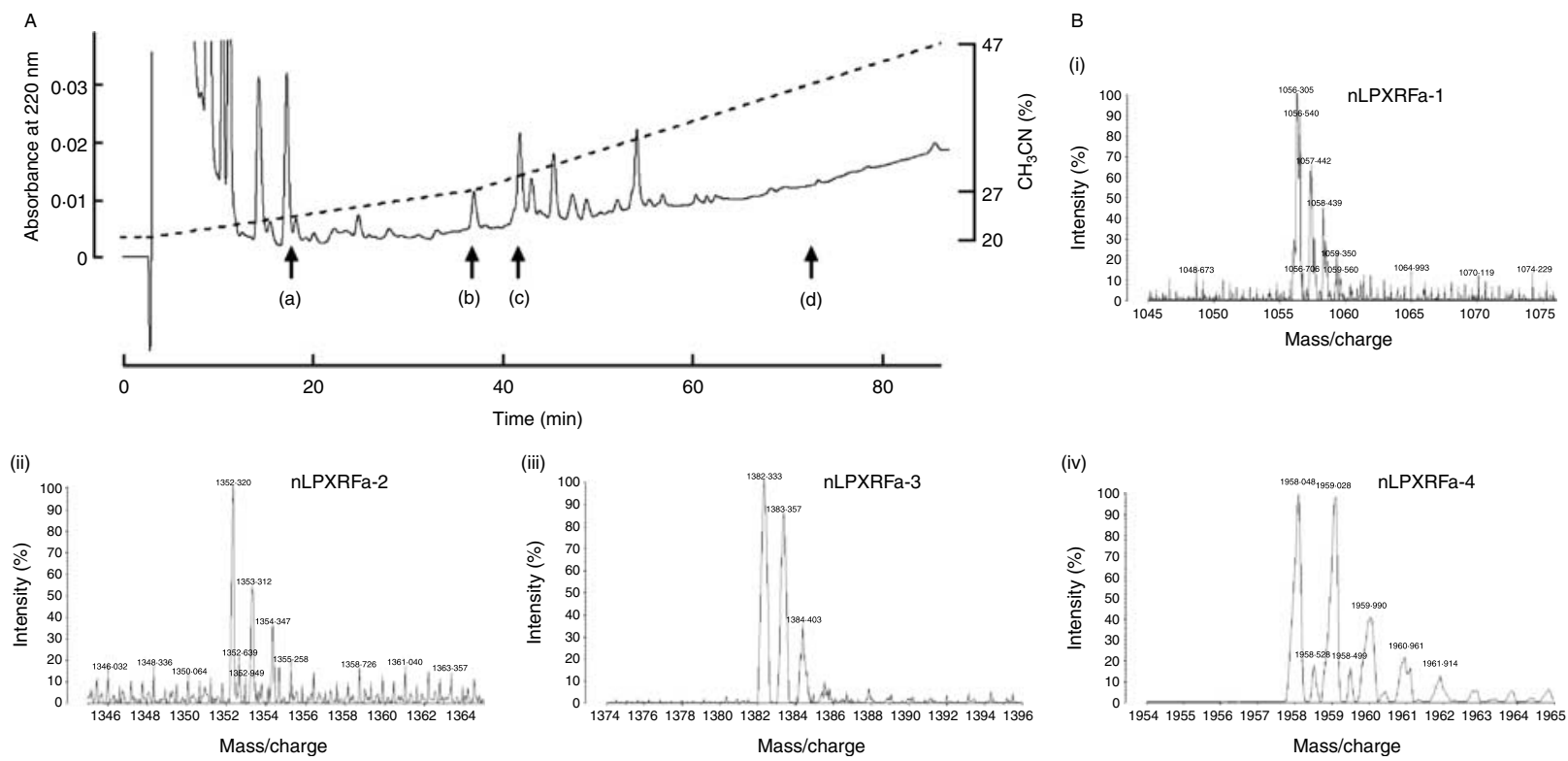

Figure 2 HPLC profile of the fGRP-immunoreactive material (IM) (A) and chromatograms of mass spectrometry (MALDI-TOF MS) of native nLPXRFa-1, $-2,-3$ and -4 (B). The IM loaded onto the column was eluted with two-step gradients of acetonitrile (20-27\%/35 min; $27-47 \% / 65$ min) containing $0.1 \%$ trifluoroacetic acid at a flow rate of $0.5 \mathrm{ml} / \mathrm{min}$, and fractioned every $2 \mathrm{~min}$ for $100 \mathrm{~min}$. Aliquots of each fraction were evaporated to dryness, dissolved in distilled water and spotted onto a nitrocellulose membrane. The immunoreactive fractions which were eluted with $21,24 \cdot 5,25 \cdot 5$ and $38 \%$ acetonitrile are indicated by the arrows $a, b, c$ and d, respectively (A). The immunoreactive materials in the extract of newt brain using the antiserum against fGRP showed molecular ion peaks of $1056 \cdot 31 \mathrm{~m} / \mathrm{z}\left([(\mathrm{M}+\mathrm{H})]^{+}\right)(\mathrm{i}), 1352 \cdot 32 \mathrm{~m} / \mathrm{z}\left([(\mathrm{M}+\mathrm{H})]^{+}\right)(\mathrm{ii}), 1382 \cdot 33$ $\mathrm{m} / \mathrm{z}\left([(\mathrm{M}+\mathrm{H})]^{+}\right)$(iii) and 1958.05 $\mathrm{m} / \mathrm{z}\left([(\mathrm{M}+\mathrm{H})]^{+}\right)$(iv) by MALDI-TOF MS (B). 
Table 2 Behavior of native and synthetic nLPXRFa on HPLC and mass spectrometry in the newt brain

\begin{tabular}{|c|c|c|c|c|c|}
\hline & \multicolumn{2}{|c|}{ Retention time on HPLC (min) } & \multicolumn{2}{|c|}{ Observed mass $\left(m / z[M+H]^{+}\right)$} & $\frac{\text { Calculated mass }\left(\mathrm{m} / \mathrm{z}[\mathrm{M}+\mathrm{H}]^{+}\right)}{\text {Synthetic }}$ \\
\hline \multicolumn{6}{|l|}{ Name } \\
\hline nLPXRFa-1 & $14-16$ & 15 & $1056 \cdot 31$ & $1056 \cdot 40$ & $1056 \cdot 60$ \\
\hline nLPXRFa-2 & $31-33$ & 32 & $1352 \cdot 32$ & $1352 \cdot 37$ & $1352 \cdot 73$ \\
\hline nLPXRFa-3 & $36-38$ & 37 & $1382 \cdot 33$ & $1382 \cdot 29$ & $1382 \cdot 79$ \\
\hline nLPXRFa-4 & $71-73$ & 71 & $1958 \cdot 05$ & $1958 \cdot 12$ & $1958 \cdot 06$ \\
\hline
\end{tabular}

Identification of mature $n L P X R F a$ peptides in the brain

As shown in Fig. 1, four nLPXRFa peptides (nLPXRFa-1, $-2,-3$ and -4$)$ were predicted to be encoded in the cDNA. In the present study, we further investigated endogenous nLPXRFa peptides in the brain by immunoaffinity purification, combined with MS. The fGRP-immunoreactive material obtained by affinity chromatography using antifGRP serum was subjected to the reversed-phase HPLC purification, and the eluate was fractionated every $2 \mathrm{~min}$ (Fig. 2A). Each purified substance was further examined by MS. The mass values of predicted peptides were previously calculated using Protein Prospector web site (http:// prospector.ucsf.edu/prospector/mshome.htm) on the basis of the sequence of nLPXRFa precursor polypeptide. Molecular ion peaks in the spectrum of each substance were observed at $1056 \cdot 31,1352 \cdot 32,1382 \cdot 33$ or $1958 \cdot 05 \mathrm{~m} / \mathrm{z}$ $\left([(\mathrm{M}+\mathrm{H})]^{+}\right)$on the MALDI-TOF MS (Fig. 2B and Table 2). These values were close to the mass number of $1352 \cdot 73$, $1056 \cdot 60,1382 \cdot 79$ and $1958.06 \mathrm{~m} / \mathrm{z}\left([(\mathrm{M}+\mathrm{H})]^{+}\right)$calculated for four deduced nLPXRFa-1, $-2,-3$ and -4 , respectively (Table 2). The predicted nLPXRFa peptides were then synthesized and their retention time on HPLC and mass numbers were confirmed. Both native and synthetic peptides showed a similar retention time on the reversed-phase HPLC and a similar molecular mass in all four LPXRFa peptides (Table 2). These results revealed that nLPXRFa-1, $-2,-3$ and -4 are produced in the newt brain in mature forms.

\section{Cellular localization of $n L P X R F$ a precursor $m R N A$ in the brain}

Localization of nLPXRFa mRNA and the mature peptide was identified by in situ hybridization and immunohistochemistry. In situ hybridization of nLPXRFa precursor mRNA was examined in the brain, using an RNA probe with a sequence complementary to that of the nLPXRFa-1, -2, -3 and -4 precursor mRNA. Immunohistochemistry was performed using anti-fGRP serum. The binding of LPXRFa peptides to the anti-fGRP serum was completely inhibited by nLPXRFa-1, -2 and -3, demonstrating the high specificity of the antiserum (Fig. 3). An intense expression of nLPXRFa precursor mRNA was detected only in the suprachiasmatic nucleus (SCN) in the hypothalamus (Fig. 4A). The control using the sense RNA probe resulted in the complete absence of the nLPXRFa precursor mRNA expression in the SCN
(Fig. 4B), suggesting that the reaction was specific for nLPXRFa mRNA. However, no cell body expressing nLPXRFa mRNA was observed in other brain regions. Cellular localization of nLPXRFa peptides was further analyzed in the serial section by immunohistochemistry using the anti-fGRP serum. As shown in Fig. 4C and E, immunoreactive cell bodies were also restricted to the SCN. No nLPXRFa-immunoreactive cell body was observed in other brain regions. In addition, immunoreactive fibers were emanating from immunoreactive SCN cells to mesencephalic and rhombencephalic regions (Fig. $4 \mathrm{C}$ and $\mathrm{E}$ ). In particular, immunoreactive nerve endings to the median eminence (ME; Fig. 4F) were derived from the SCN via ventral infundibular regions (Fig. 4C and E). As shown in Fig. 4D, a complete absence of the immunoreaction was observed by preincubation of the antiserum with an excess of synthetic nLPXRFa-1. Preincubation of the anti-fGRP serum with synthetic nLPXRFa-2 or nLPXRFa-3 also resulted in the disappearance of the reaction product (data not shown).

Effect of melatonin administration on the expression of $n L P X R F a$ peptide precursor $m R N A$

To investigate whether melatonin is involved in the induction of nLPXRFa peptide, the expression of nLPXRFa peptide precursor mRNA in the diencephalon was measured after

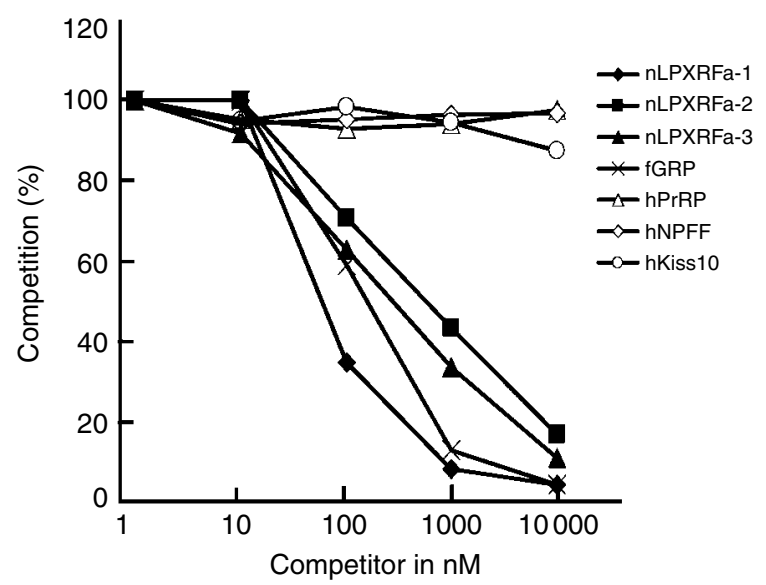

Figure 3 Competition binding of nLPXRFa peptides to the antiserum raised against fGRP with various RFa peptides as measured by competitive ELISA. 

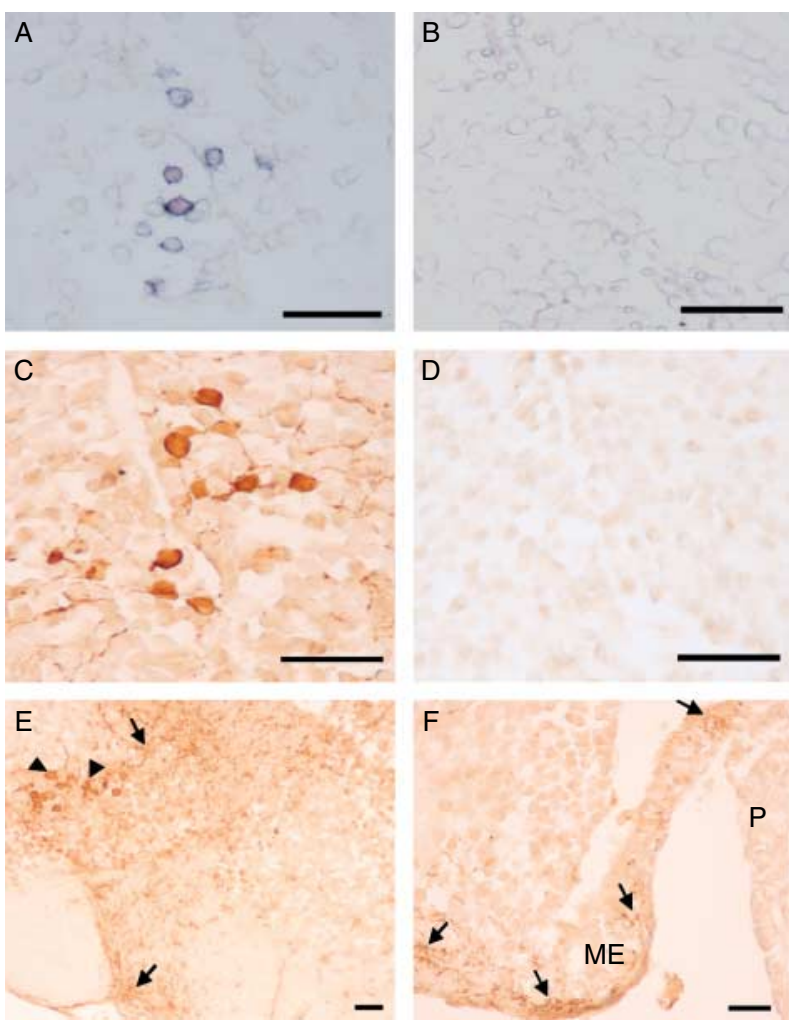

Figure 4 Cellular localization of nLPXRFa peptide mRNA and peptide in the newt brain. The expression of nLPXRFa peptide mRNA and the peptide were localized by in situ hybridization and immunocytochemistry, respectively. Distribution of nLPXRFa peptide mRNA in the suprachiasmatic nucleus ( $\mathrm{SCN}$ ) as observed in the frontal (A) section of the newt brain. Lack of hybridization of nLPXRFa peptide mRNA by the sense probe (control) in a frontal section is evident (B). Immunohistochemical staining of a frontal (C) or sagittal (E and F) was carried out with antiserum against fGRP. A complete absence of immunoreactions was observed by preincubation of the fGRPantiserum with synthetic nLPXRFa-1, -2 or -3 (D) (data not shown for nLPXRFa-2 and -3). Arrows and arrowheads in $\mathrm{E}$ and $\mathrm{F}$ indicate immunoreactive fibers and cells. $\mathrm{ME}$, median eminence; $\mathrm{P}$, pituitary. Scale bars represent $50 \mu \mathrm{m}$.

melatonin administration to newts. As shown in Fig. 5A, melatonin administration through i.p. injection to newts caused a significant increase in the nLPXRFa precursor mRNA level $(P<0 \cdot 05)$. Melatonin administration through loading in aquarium water also significantly increased nLPXRFa peptide precursor mRNA level (Fig. 5B; $P<0 \cdot 05$ ).

\section{Discussion}

In amphibians, the presence of LPXRFa peptides in the urodele brain is as yet unknown, unlike for those in the anuran brain. In the present study, we demonstrated the presence of LPXRFa peptides in the brain of the newt, which is an amphibian species of the urodele class. Thus, we can now generalize the presence of LPXRFa peptides in amphibians. As summarized in Table 3, all the identified LPXRFa peptides in the brains of newts (this study) and other vertebrates, such as mammals, birds, frogs and fish, include a -LPXRFa sequence $(\mathrm{X}=\mathrm{L}$ or $\mathrm{Q})$ at their C-termini (Tsutsui et al. 2000, Fukusumi et al. 2001, Koda et al. 2002, Sawada et al. 2002b, Ukena et al. 2002, 2003b, Osugi et al. 2004, Ubuka et al. 2008, 2009a,b).

In the present study, we first identified a cDNA encoding nLPXRFa peptides from the newt brain by a combination of $3^{\prime}$ and $5^{\prime}$ RACE. We predicted that the nLPXRFa peptide transcript would be translated with $\mathrm{Met}^{1}$, because a hydropathy plot analysis of the nLPXRFa peptide precursor demonstrated that the most hydrophobic moiety, which is typical in a signal peptide region, is followed $\mathrm{Met}^{1}$. The cleavage site of the signal peptide was the $\mathrm{Gly}^{25}-\mathrm{Leu}^{26}$ bond. The deduced precursor polypeptide consisted of 233 amino acid residues, encoding four putative LPXRFa peptide sequences, i.e. nLPXRFa-1, $-2,-3$ and -4 (Fig. 1). All four peptides shared the C-terminal sequence LPXRF motif (with $X$ representing $L$ in $n L P X R F a-2$, and $Q$ in $n L P X R F a-1,-3$ and -4$)$. In the frog, it has been demonstrated that the proprotein convertases $\mathrm{PC} 1$ and $\mathrm{PC} 2$, which are responsible for the processing of neuropeptide precursors, are abundantly expressed in the brain, including the hypothalamus (Vieau et al. 1998, Gangnon et al. 1999). Several proprotein convertases (PCs) are usually considered to recognize and cleave a precursor polypeptide at the Lys/Arg-(Xaa) ${ }_{n}$-Lys/ Arg sequence $(n=0,2,4$ or 6; reviewed in Seidah \& Chretien (1999)). Their sequences of putative nLPXRFa-2, -3 and -4 are flanked on both ends by the typical endoproteolytic sequences, i.e. RK or RFGR (Fig. 1), suggesting that mature peptides may be generated. Although, nLPXRFa-1 has the cleavage sequences of RFGR in the C-terminal sequence, $\mathrm{N}$-terminal sequence did not follow typical endoproteolytic sequence (Fig. 1). Therefore, some other N-terminal processing mechanism(s) may be present in this precursor polypeptide. On the other hand, Gly preceding the

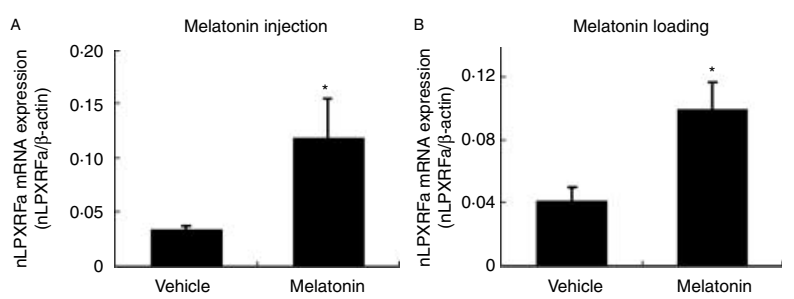

Figure 5 Effect of melatonin administration on the expression of nLPXRFa peptide precursor mRNA in the newt brain. Melatonin was administered by means of i.p. injection to newts and brains were collected after $1 \mathrm{~h}$ of injection (A). Melatonin was administered by means of loading into water aquarium containing newts for 2 weeks (B). Control newts received saline alone by means of i.p. injection or loading into water aquarium (A and B). Each column and vertical line represent the mean \pm S.E.M. $(n=6$ samples; one sample from one newt). ${ }^{*} P<0 \cdot 05$ versus vehicle by Student's $t$-test. 
Table 3 Amino acid sequences of LPXRFa peptides in newts and other vertebrates

\begin{tabular}{|c|c|c|c|}
\hline Sequence & Animal & Name & References \\
\hline MPHSANLPLRFa & Human & RFRP-1 & Ubuka et al. (2009b) \\
\hline VPNLPQRFa & Human & RFRP-3 & Ubuka et al. (2009b) \\
\hline SGRNMEVSLVRQVLNLPQRFa & Monkey & RFRP-3 & Ubuka et al. (2009a) \\
\hline SLTFEEVKDWAPKIKMNKPVVNKMPPSAANLPLRFa & Cow & RFRP-1 & Fukusumi et al. (2001) \\
\hline AMAHLPLRLGKNREDSLSRWVPNLPQRFa & Cow & RFRP-3 & Yoshida et al. (2003) \\
\hline SVTFQELKDWGAKKDIKMSPAPANKVPHSAANLPLRFa & Rat & RFRP- $1^{\mathrm{a}}$ & Hinuma et al. (2000) \\
\hline ANMEAGTMSHFPSLPQRFa & Rat & RFRP-3 & Ukena et al. (2002) \\
\hline SPAPANKVPHSAANLPLRFa & Hamster & RFRP $-1^{\mathrm{a}}$ & Kriegsfeld et al. (2006) \\
\hline ILSRVPSLPQRFa & Hamster & RFRP $-3^{\mathrm{a}}$ & Kriegsfeld et al. (2006) \\
\hline SIKPSAYLPLRFa & Quail & $\mathrm{GnlH}$ & Tsutsui et al. (2000) \\
\hline SLNFEEMKDWGSKNFMKVNTPTVNKVPNSVANLPLRFa & Quail & GnlH-RP- $1^{\mathrm{a}}$ & Satake et al. (2001) \\
\hline SSIQSLLNLPQRFa & Quail & GnlH-RP-2 & Satake et al. (2001) \\
\hline SIRPSAYLPLRFa & Chicken & $\mathrm{GnlH}^{\mathrm{a}}$ & Ikemoto \& Park (2005) \\
\hline SLNFEEMKDWGSKNFLKVNTPTVNKVPNSVANLPLRFa & Chicken & GnlH-RP-1 ${ }^{\mathrm{a}}$ & Ikemoto \& Park (2005) \\
\hline SSIQSLLNLPQRFa & Chicken & GnlH-RP-2 ${ }^{\mathrm{a}}$ & Ikemoto \& Park (2005) \\
\hline SIKPFSNLPLRFa & Sparrow & $\mathrm{GnlH}^{\mathrm{a}}$ & Osugi et al. (2004) \\
\hline SLNFEEMEDWGSKDI I KMNPFTASMPNSVANLPLRFa & Sparrow & GnlH-RP-1 ${ }^{\mathrm{a}}$ & Osugi et al. (2004) \\
\hline SPLVKGSSQSLLNLPQRFa & Sparrow & GnlH-RP-2 ${ }^{\mathrm{a}}$ & Osugi et al. (2004) \\
\hline SIKPFANLPLRFa & Starling & GnlH & Ubuka et al. (2008) \\
\hline SLNFDEMEDWGSKDIIKMNPFTVSKMPNSVANLPLRFa & Starling & GnlH-RP-1 ${ }^{\mathrm{a}}$ & Ubuka et al. (2008) \\
\hline GSSQSLLNLPQRFa & Starling & GnlH-RP-2 ${ }^{\mathrm{a}}$ & Ubuka et al. (2008) \\
\hline SLKPAANLPLRFa & Frog & fGRP/R-RFa & $\begin{array}{l}\text { Koda et al. (2002) } \\
\text { and Chartrel et al. (2002) }\end{array}$ \\
\hline SIPNLPQRFa & Frog & fGRP-RP-1 & Ukena et al. $(2003 b)$ \\
\hline YLSGTKVQSMANLPQRFa & Frog & fGRP-RP-2 & Ukena et al. (2003b) \\
\hline AQYTNHFVHSLDTLPLRFa & Frog & fGRP-RP-3 & Ukena et al. (2003b) \\
\hline PTHLHANLPLRFa & Goldfish & gfLPXRFa- $1^{\mathrm{a}}$ & Sawada et al. (2002b) \\
\hline AKSNINLPQRFa & Goldfish & gfLPXRFa- $2^{a}$ & Sawada et al. (2002b) \\
\hline SGTGSATLPQRFa & Goldfish & gfLPXRFa-3 & Sawada et al. (2002b) \\
\hline SVPNLPQRFa & Newt & nLPXRFa-1 & This study \\
\hline MPHASANLPLRFa & Newt & nLPXRFa-2 & This study \\
\hline SIQPLANLPQRFa & Newt & nLPXRFa-3 & This study \\
\hline APSAGQFIQTLANLPQRFa & Newt & nLPXRFa-4 & This study \\
\hline
\end{tabular}

aputative LPXRFa peptides. C-terminal LPXRFa $(\mathrm{X}=\mathrm{L}$ or $\mathrm{Q})$ motifs are shown in bold.

C-terminal cleavage site may serve as a C-terminal amidation signal (Bradbury et al. 1982, Suzuki et al. 1990, Eipper et al. 1991). Moreover, a series of mass spectrometric analyses verified the expression of nLPXRFa-1 (SVPNLPQRFa), nLPXRFa-2 (MPHASANLPLRFa), nLPXRFa-3 (SIQPLANLPQRFa) and nLPXRFa-4 (APSAGQFIQTLANLP$\mathrm{QRFa}$ ) as mature endogenous ligands. From the previous (Tsutsui et al. 2000, Fukusumi et al. 2001, Satake et al. 2001, Koda et al. 2002, Sawada et al. 2002a,b, Ukena et al. 2002, Yoshida et al. 2003, Ubuka et al. 2008, 2009a,b) and present findings (see Fig. 2 and Table 2), it may be stated that the presence of LPXRFa peptides is conserved in vertebrate brains.

Identification of the cells expressing nLPXRFa precursor mRNA in the brain must be taken into account when studying the action of neuropeptides. In the present study, we therefore characterized the site showing the expression of nLPXRFa mRNA by in situ hybridization. The nLPXRFa mRNA expression was localized in the SCN in the newt hypothalamus. The SCN cells expressing nLPXRFa mRNA was also stained by the antiserum that cross-reacts with nLPXRFa peptides. No cell body expressing nLPXRFa
mRNA or nLPXRFa was observed in other brain regions. In a previous study in bullfrogs (Koda et al. 2002), the cell bodies and terminals containing fGRP were localized immunohistochemically in the SCN and ME, respectively. It was also demonstrated earlier that the frog $\mathrm{ME}$ receives innervation from SCN neurons (Carr et al. 1991, D'Aniello et al. 1996). Thus, the present results obtained by in situ hybridization and immunohistochemical analysis are in agreement with these previous findings. We recently identified novel hypothalamic neuropeptides containing a C-terminal LPXRFa sequence (LPXRFa peptides) in the avian and amphibian species: $\mathrm{GnIH}$ and its related peptides GnIH-RP-1 and GnIH-RP-2 in the quail (Tsutsui et al. 2000, Satake et al. 2001), fGRP and its related peptides fGRPRP-1, fGRP-RP-2 and fGRP-RP-3 in the bullfrog (Koda et al. 2002, Sawada et al. 2002a, Ukena et al. 2003b). In addition, RFRPs, which are the orthologous peptides of $\mathrm{GnIH}$, were identified in mammals: bovine RFRP-1 (Fukusumi et al. 2001), rat RFRP-3 (Ukena et al. 2002), primate RFRP-3 (Ubuka et al. 2009a) and human RFRP-1 and RFRP-3 (Ubuka et al. 2009b). The identified LPXRFa peptides are summarized in Table 3. Most of the LPXRFa peptides have 
been reported as hypophysiotropic ligands. fGRP, the anuran LPXRFa peptide, stimulated the release of $\mathrm{GH}$, and fGRPRP-2 stimulated GH and PRL release (Koda et al. 2002, Ukena et al. 2003b). Therefore, it is possible that our identified nLPXRFa peptides act as endogenous ligands in the newt hypothalamo-hypophysial system to regulate pituitary hormone release. Further study is needed to determine the biological action of nLPXRFa peptides in urodele.

A regulatory mechanism(s) governing nLPXRFa peptide mRNA expression is essential to understand the physiological significance of novel newt neuropeptides. Recently, we reported that melatonin induces $\mathrm{GnIH}$ expression (Ubuka et al. 2005) and its release (Chowdhury et al. 2010) in the quail brain. Furthermore, we also demonstrated that the expressions of fGRP and fGRP-RPs in the anuran brain are also induced by melatonin (Chowdhury et al. 2008). Therefore, we hypothesized that melatonin may also be involved in the induction of nLPXRFa peptide precursor mRNA expression in urodele. Melatonin administration to newts through i.p. injection or adding in water aquarium under continuous lighting increased the expression of nLPXRFa peptide precursor mRNA. In newts, as in all vertebrates, melatonin is secreted into the blood in the dark (Chiba et al. 2005). In this study, we administrated melatonin under continuous light to make sure that no (or insignificant) amount of endogenous melatonin is produced. Furthermore, it was demonstrated that highest melatonin-binding activities were shown to occur in the optic tracts and in the suprachiasmatic area of the hypothalamus in newt (Tavolaro et al. 1995). In the current study, we demonstrated that the expression of nLPXRFa peptide precursor mRNA is restricted in the SCN. Thus, from the previous and present studies, it could be stated that the increased nLPXRFa peptide precursor mRNA is likely to be due to the direct effect of exogenous melatonin. Thus, melatonin may play a role to induce LPXRFa peptide precursor mRNA expressions both in anuran and urodele brain.

In conclusion, urodele hypothalamus expresses LPXRFa peptides like anuran, and the expression of nLPXRFa peptides is regulated by melatonin. The localization of nLPXRFa peptides indicates that these peptides may be involved in the regulation of pituitary hormone release.

\section{Declaration of interest}

The authors declare that there is no conflict of interest that could be perceived as prejudicing the impartiality of the research reported.

\section{Funding}

This work was supported in part by Grants-in-Aid for Scientific Research from the Ministry of Education, Science and Culture, Japan (18107002, 22132004 and 22227002 to K T).

\section{References}

Amano M, Moriyama S, Iigo M, Kitamura S, Amiya N, Yamamori K, Ukena K \& Tsutsui K 2006 Novel fish hypothalamic neuropeptides stimulate the release of gonadotrophins and growth hormone from the pituitary of sockeye salmon. Journal of Endocrinology 188 417-423. (doi:10.1677/joe.1. 06494)

Bradbury AF, Finnie MD \& Smyth DG 1982 Mechanism of C-terminal amide formation by pituitary enzymes. Nature 298 686-688. (doi:10.1038/ 298686a0)

Carr JA, Norris DO \& Samora A 1991 Organization of tyrosine hydroxylaseimmunoreactive neurons in the di- and mesencephalon of the American bullfrog (Rana catesbeiana) during metamorphosis. Cell and Tissue Research 263 155-163. (doi:10.1007/BF00318411)

Chartrel N, Dujardin C, Leprince J, Desrues L, Tonon MC, Cellier E, Cosette P, Jouenne T, Simonnet G \& Vaudry H 2002 Isolation, characterization, and distribution of a novel neuropeptide, Rana RFamide (R-RFa), in the brain of the European green frog Rana esculenta. Journal of Comparative Neurology 448 111-127. (doi:10.1002/cne.10253)

Chiba A, Hattori A \& Iigo M 2005 Daily and circadian variations of the pineal and ocular melatonin contents and their contributions to the circulating melatonin in the Japanese newt, Cynops pyrrhogaster. Zoological Science $\mathbf{2 2}$ 65-70. (doi:10.2108/zsj.22.65)

Chowdhury VS, Yamamoto K, Saeki I, Hasunuma I, Shimura T \& Tsutsui K 2008 Melatonin stimulates the release of growth hormone and prolactin by a possible induction of the expression of frog growth hormone-releasing peptide and its related peptide- 2 in the amphibian hypothalamus. Endocrinology 149 962-970. (doi:10.1210/en.2007-1427)

Chowdhury VS, Yamamoto K, Ubuka T, Bentley GE, Hattori A \& Tsutsui K 2010 Melatonin stimulates the release of gonadotropin-inhibitory hormone by the avian hypothalamus. Endocrinology 151 271-280. (doi:10.1210/en. 2009-0908)

D’Aniello B, Vallarino M, Pinelli C, Fiorentino M \& Rastogi RK 1996 Neuropeptide Y: localization in the brain and pituitary of the developing frog (Rana esculenta). Cell and Tissue Research 285 253-259. (doi:10.1007/ s004410050642)

Eipper BA, Perkins SN, Husten EJ, Johnson RC, Keutmann HT \& Mains RE 1991 Peptidyl $\boldsymbol{\alpha}$-hydroxyglycine $\boldsymbol{\alpha}$-amidating lyase. Journal of Biological Chemistry 266 7827-7833.

Fukusumi S, Habata Y, Yoshida H, Iijima N, Kawamata Y, Hosoya M, Fujii R, Hinuma S, Kitada C, Shintani Y et al. 2001 Characteristics and distribution of endogenous RFamide-related peptide-1. Biochimica et Biophysica Acta 1540 221-232. (doi:10.1016/S0167-4889(01)00135-5)

Gangnon F, Danger JM, Jegou S, Vieau D, Seidah NG \& Vaudry H 1999 Molecular cloning, characterization of cDNA, and distribution of mRNA encoding the frog prohormone convertase PC1. Journal of Comparative Neurology 405 160-172. (doi:10.1002/(SICI)1096-9861(19990308) 405:2<160::AID-CNE2 > 3.0.CO;2-Y)

Hinuma S, Shintani Y, Fukusumi S, Iijima N, Matsumoto Y, Hosoya M, Fujii R, Watanabe T, Kikuchi K, Terao Y et al. 2000 New neuropeptides containing carboxy-terminal RFamide and their receptor in mammals. Nature Cell Biology 2 703-708. (doi:10.1038/35036326)

Ikemoto T \& Park MK 2005 Chicken RFamide-related peptide (GnIH) and two distinct receptor subtypes: identification, molecular characterization, and evolutionary considerations. Journal of Reproduction and Development $\mathbf{5 1}$ 359-377. (doi:10.1262/jrd.16087)

Koda A, Ukena K, Teranishi H, Ohta S, Yamamoto K, Kikuyama S \& Tsutsui K 2002 A novel amphibian hypothalamic neuropeptide: isolation, localization, and biological activity. Endocrinology 143 411-419. (doi:10. 1210/en.143.2.411)

Kriegsfeld LJ, Mei DF, Bentley GE, Ubuka T, Mason AO, Inoue K, Ukena K, Tsutsui K \& Silver R 2006 Identification and characterization of a gonadotropin-inhibitory system in the brains of mammals. PNAS 103 2410-2415. (doi:10.1073/pnas.0511003103)

Mason AO, Duffy S, Zhao S, Ubuka T, Bentley GE, Tsutsui K, Silver R \& Kriegsfeld LJ 2010 Photoperiod and reproductive condition are associated 
with changes in RFamide-related peptide (RFRP) expression in Syrian hamsters (Mesocricetus auratus). Journal of Biological Rhythms 25 176-185. (doi:10.1177/0748730410368821)

Osugi T, Ukena K, Bentley GE, O’Brien S, Moore IT, Wingfield JC \& Tsutsui K 2004 Gonadotropin-inhibitory hormone in Gambel's whitecrowned sparrow (Zonotrichia leucophrys gambelii): cDNA identification, transcript localization and functional effects in laboratory and field experiments. Journal of Endocrinology 182 33-42. (doi:10.1677/joe.0. 1820033)

Osugi T, Ukena K, Sower SA, Kawauchi H \& Tsutsui K 2006 Evolutionary origin and divergence of PQRFamide peptides and LPXRFamide peptides in the RFamide peptide family insights from novel lamprey RFamide peptides. FEBS Journal 273 1731-1743. (doi:10.1111/j.1742-4658.2006. 05187.x)

Price DA \& Greenberg MJ 1977 Structure of a molluscan cardioexcitatory neuropeptide. Science 197 670-671. (doi:10.1126/science. 877582)

Raffa RB 1988 The action of FMRFamide (Phe-Met-Arg-Phe-NH $\mathrm{N}_{2}$ ) and related peptides on mammals. Peptides 9 915-922. (doi:10.1016/01969781(88)90141-6)

Rastogi RK, D’Aniello B, Pinelli C, Fiorentino M, Di Fiore MM, Di Meglio M \& Lela L 2001 FMRFamide in the amphibian brain: a comprehensive survey. Microscopy Research and Technique 54 158-172. (doi:10.1002/jemt. 1130)

Satake H, Hisada M, Kawada T, Minakata H, Ukena K \& Tsutsui K 2001 Characterization of a cDNA encoding a novel avian hypothalamic neuropeptide exerting an inhibitory effect on gonadotropin release. Biochemical Journal 354 379-385. (doi:10.1042/0264-6021:3540379)

Sawada K, Ukena K, Kikuyama S \& Tsutsui K 2002a Identification of cDNA encoding a novel amphibian growth hormone-releasing peptide and localization of its transcript. Journal of Endocrinology 174 395-402. (doi:10. 1677/joe.0.1740395)

Sawada K, Ukena K, Satake H, Iwakoshi E, Minakata H \& Tsutsui K $2002 b$ Novel fish hypothalamic neuropeptide: cloning of a cDNA encoding the precursor polypeptide and identification and localization of the mature peptide. European Journal of Biochemistry 269 6000-6008. (doi:10.1046/j. 1432-1033.2002.03351.x)

Seidah NG \& Chrétien M 1999 Proprotein and prohormone convertases: a family of subtilases generating diverse bioactive polypeptides. Brain Research 848 45-62. (doi:10.1016/S0006-8993(99)01909-5)

Suzuki K, Shimoi H, Iwasaki Y, Kawahara T, Matsuura Y \& Nishikawa Y 1990 Elucidation of amidating reaction mechanism by frog amidating enzyme, peptidylglycine $\alpha$-hydroxylating monooxygenase, expressed in insect cell culture. EMBO Journal 9 4259-4265.

Tavolaro R, Canonaco M \& Franzoni MF 1995 Comparison of melatoninbinding sites in the brain of two amphibians: an autoradiographic study. Cell and Tissue Research 279 613-617. (doi:10.1007/BF00318173)

Tsutsui K 2009 Review: a new key neurohormone controlling reproduction, gonadotropin-inhibitory hormone $(\mathrm{GnIH})$ : biosynthesis, mode of action and functional significance. Progress in Neurobiology 88 76-88. (doi:10.1016/ j.pneurobio.2009.02.003)

Tsutsui K 2010 Review: phylogenetic aspects of gonadotropin-inhibitory hormone $(\mathrm{GnIH})$ and its homologs in vertebrates. Annals of the New York Academy of Sciences 1200 75-84. (doi:10.1111/j.1749-6632. 2010.05510.x)

Tsutsui K \& Ukena K 2006 Review: hypothalamic LPXRF-amide peptides in vertebrates: identification, localization and hypophysiotropic activity. Peptides 27 1121-1129. (doi:10.1016/j.peptides.2005.06.036)

Tsutsui K \& Osugi T 2009 Evolutionary origin and divergence of GnIH and its homologous peptides (review). General and Comparative Endocrinology 161 30-33. (doi:10.1016/j.ygcen.2008.10.002)

Tsutsui K, Saigoh E, Ukena K, Teranishi H, Fujisawa Y, Kikuchi M, Ishii S \& Sharp PJ 2000 A novel avian hypothalamic peptide inhibiting gonadotropin release. Biochemical and Biophysical Research Communications 275 661-667. (doi:10.1006/bbrc.2000.3350)
Tsutsui K, Bentley GE, Bedecarrats G, Osugi T, Ubuka T \& Kriegsfeld LJ 2010a Review: gonadotropin-inhibitory hormone (GnIH) and its control of central and peripheral reproductive function. Frontiers in Neuroendocrinology 31 284-295. (doi:10.1016/j.yfrne.2010.03.001)

Tsutsui K, Bentley GE, Kriegsfeld LJ, Osugi T, Seong JY \& Vaudry H 2010 b Review: discovery and evolutionary history of $\mathrm{GnIH}$ and kisspeptin: new key neuropeptides controlling reproduction. Journal of Neuroendocrinology 22 716-727. (doi:10.1111/j.1365-2826.2010.02018.x)

Ubuka T, Ueno M, Ukena K \& Tsutsui K 2003 Developmental changes in gonadotropin-inhibitory hormone in the Japanese quail (Coturnix japonica) hypothalamo-hypophysial system. Journal of Endocrinology 178 311-318. (doi:10.1677/joe.0.1780311)

Ubuka T, Bentley GE, Ukena K, Wingfield JC \& Tsutsui K 2005 Melatonin induces the expression of gonadotropin-inhibitory hormone in the avian brain. PNAS 102 3052-3057. (doi:10.1073/pnas.0403840102)

Ubuka T, Ukena K, Sharp PJ, Bentley GE \& Tsutsui K 2006 Gonadotropininhibitory hormone inhibits gonadal development and maintenance by decreasing gonadotropin synthesis and release in quail brain. Endocrinology 147 1187-1194. (doi:10.1210/en.2005-1178)

Ubuka T, Kim S, Huang YC, Reid J, Jiang J, Osugi T, Chowdhury VS, Tsutsui K \& Bentley GE 2008 Gonadotropin-inhibitory hormone neurons interact directly with gonadotropin-releasing hormone-I and -II neurons in European starling brain. Endocrinology 149 268-278. (doi:10.1210/en.2007-0983)

Ubuka T, Kitani HLM, Suzuuchi A, Pham V, Cadigan PA, Wang A, Chowdhury VS, Tsutsui K \& Bentley GE 2009a Gonadotropin-inhibitory hormone identification, cDNA cloning, and distribution in rhesus macaque brain. Journal of Comparative Neurology 517 841-855. (doi:10.1002/cne. 22191)

Ubuka T, Morgan K, Pawson AJ, Osugi T, Chowdhury VS, Minakata H, Tsutsui K, Millar RP \& Bentley GE 2009 b Identification of human GnIH homologs, RFRP-1 and RFRP-3, and the cognate receptor, GPR147 in the human hypothalamic pituitary axis. PLoS ONE 4 e8400. (doi:10.1371/ journal.pone.0008400)

Ukena K \& Tsutsui K 2005 Review: a new member of the hypothalamic RF-amide peptide family, LPXRF-amide peptides: structure, localization and function. Mass Spectrometry Reviews 24 469-486. (doi:10.1002/mas.20031)

Ukena K, Kohchi C \& Tsutsui K 1999 Expression and activity of $3 \beta$-hydroxysteroid dehydrogenase $/ \Delta^{5}-\Delta^{4}$-isomerase in the rat Purkinje neuron during neonatal life. Endocrinology 140 805-813. (doi:10.1210/en.140.2.805)

Ukena K, Iwakoshi E, Minakata H \& Tsutsui K 2002 A novel rat hypothalamic RFamide-related peptide identified by immunoaffinity chromatography and mass spectrometry. FEBS Letters $\mathbf{5 1 2} 255-258$. (doi:10.1016/S0014-5793(02)02275-5)

Ukena K, Ubuka T \& Tsutsui K 2003a Distribution of a novel avian gonadotropin-inhibitory hormone in the quail brain. Cell and Tissue Research 312 73-79. (doi:10.1007/s00441-003-0700-x)

Ukena K, Koda A, Yamamoto K, Kobayashi T, Iwakoshi-Ukena E, Minakata H, Kikuyama S \& Tsutsui K 2003b Novel neuropeptides related to frog growth hormone-releasing peptides: isolation, sequence, and functional analysis. Endocrinology 144 3879-3884. (doi:10.1210/en. 2003-0359)

Vieau D, Gangnon F, Jegou S, Danger JM \& Vaudry H 1998 Characterization of the cDNA encoding the prohormone convertase PC2 and localization of the mRNA in the brain of the frog Rana ridibunda. Molecular Brain Research 63 1-13. (doi:10.1016/S0169-328X(98)00235-6)

Yoshida H, Habata Y, Hosoya M, Kawamata Y, Kitada C \& Hinuma S 2003 Molecular properties of endogenous RFamide-related peptide- 3 and its interaction with receptors. Biochimica et Biophysica Acta 1593 151-157. (doi:10.1016/S0167-4889(02)00389-0)

\section{Received in final form 26 January 2011 \\ Accepted 16 February 2011 \\ Made available online as an Accepted Preprint 16 February 2011}

